\title{
Do Institutional Investors Influence R\&D Investment Policy in Firms with High Information Asymmetry?
}

\author{
Ricky W. Scott ${ }^{1}$ \\ ${ }^{1}$ Donald R. Tapia School of Business, Saint Leo University, Saint Leo, Florida, USA \\ Correspondence: Ricky W. Scott, Donald R. Tapia School of Business, University Campus - MC 2011, P.O. Box \\ 6665, Saint Leo University, Saint Leo, FL 33543-6665, USA. Tel: 1-352-588-8304. E-mail: \\ ricky.scott@saintleo.edu
}

Received: August 1, 2014

Accepted: August 12, 2014

Online Published: September 25, 2014

doi:10.5539/ibr.v7n10p22

URL: http://dx.doi.org/10.5539/ibr.v7n10p22

\begin{abstract}
This paper seeks to determine if institutional investors influence corporate research and development (R\&D) investment policies by encouraging $R \& D$ investment in firms with high information asymmetry. The effect of changes in institutional investor levels to subsequent changes in R\&D investment levels are examined using firm and year fixed effect regressions and difference-GMM regressions. Increased institutional ownership leads to increased $R \& D$ investment and this relationship is stronger in firms with higher information asymmetry. Institutional investors encourage higher $R \& D$ investment primarily in firms with high information asymmetry indicating they have an advantage in discerning the value of R\&D investments in such firms. Institutions are an important and increasing force in U.S. stock ownership. The results in this paper indicate that institutional investors have an advantage in discerning the value of R\&D investments in firms with high information asymmetry. The presence of institutional investors encourages the management of such firms to make long-term investments in $R \& D$.
\end{abstract}

Keywords: institutional investors, R\&D, investment policy, managerial myopia

\section{Introduction}

The amount of investment to make in research and development (R\&D) is a key financial decision for many companies. Theoretically, R\&D investment should only be made if it is beneficial to shareholders. Support for the point of view that R\&D investment is generally beneficial to shareholders is provided by the finding of Chan, Lakonishok, and Sougiannis (2001) that higher R\&D and increases in R\&D are positively associated with future returns. Still, management may be hesitant to increase R\&D because investors tend to underreact to the benefits of $R \& D$ increases and the benefits from $R \& D$ investment are much more uncertain than the benefits from other investments such as investments in property, plant, and equipment (Eberhart, Maxwell, \& Siddique, 2004; Kothari, Laguerre, \& Leone, 2002).

The uncertain nature of $R \& D$ investment can incentivize management to underinvest in $R \& D$ to the detriment of shareholders (Porter, 1992). Management may choose to increase short-term earnings by underinvesting in R\&D. This outcome is made possible because $R \& D$ is expensed immediately while its benefits are often not recognized for years. This incentive to underinvest in $\mathrm{R} \& \mathrm{D}$ can create an agency problem if management decides to underinvest to benefit themselves in the short-term at the expense of long-term shareholder interests. Managers have been shown to knowingly invest at a sub-optimal level in R\&D to meet earnings-based compensation goals (Harter \& Harikumar, 2004), to meet an earnings target (Baber, Fairfield, \& Haggard, 1991; Graham, Harvey, \& Rajgopal, 2005), to facilitate a pending stock issuance (Bhojraj \& Libby, 2005), and to exceed analysts' earnings forecasts (Bhojraj, Hribar, Picconi, \& McInnis, 2009).

If managers underinvest in $\mathrm{R} \& \mathrm{D}$, institutional investors may serve to mitigate, exacerbate or have no effect on this problem. Institutional investors such as banks, insurance companies, mutual funds, pension funds, and charitable endowments own nearly $70 \%$ of the shares of U.S. corporations (Bogle, 2010). Therefore, it is likely that they have the clout to affect management decisions on many matters at many companies. Previous research has provided evidence that institutions encourage (Bange \& De Bondt, 1998) and discourage (Samuel, 2000) R\&D investment. Still, there is ample evidence that institutional investors are more effective monitors than other investors (Almazan, Hartzell, \& Starks, 2005; Maug, 1998; Parrino, Sias, \& Starks, 2003). 
I determine the influence that institutional investors have on R\&D investment. Then, I analyze the effect that information asymmetry has on this influence.

Firms in which investors know relatively more about the firm's future prospects are considered low information asymmetry firms. The importance of information asymmetry in R\&D budgets to investors is demonstrated by Aboody and Lev (2000) who find that R\&D is a major contributor to insider gains and information asymmetry between insiders and investors.

Information asymmetry is likely to be important to the relationship between institutional investors and R\&D. Institutional investors have an informational advantage over other shareholders which varies with firm characteristics and information asymmetry (Bennett, Sias, \& Starks, 2003). Institutions have an informational advantage in newly public firms (Field \& Lowry, 2009) and seasoned equity offerings (Chemmanur, $\mathrm{He}, \& \mathrm{Hu}$, 2009) which is largely the result of better analysis of publicly available information. If institutional investors encourage R\&D investment more in low information asymmetry firms, it indicates that they are not more effective than other investors at monitoring firms which are difficult to monitor. Conversely, if institutional investors have a more positive effect on R\&D investment in high information asymmetry firms, it shows that institutional investors are effective monitors of firms that are difficult for other investors to monitor.

My results indicate that institutional investors encourage higher R\&D investment overall. I also provide evidence that institutional investors induce R\&D investment more effectively in firms with high information asymmetry.

\section{Literature Review}

There is evidence that increased R\&D investment is viewed favorably by investors (Sundaram, John, \& John, 1996). Despite this benefit, management may have incentives to underinvest in R\&D. Management might underinvest because of their concentrated wealth in the firm leads them to be risk averse (Stein, 1988) or because they wish to manage earnings (Stein, 1989) or because they wish to protect earnings-based compensation (Bange \& De Bondt, 1998). Management also may underinvest to avoid hostile takeovers and to appease influential investors with short time horizons (Froot, Perold, \& Stein, 1992; Stein, 1988). In contrast, increased investment may lead to increased firm size and increased power and compensation for managers (Jensen, 1986).

Empirical studies provide support for the assertion that managers sometimes engage in managerial myopia (sacrificing long-term value creation to meet short-term goals) by underinvesting in R\&D. Holden and Lundstrum (2009) report that managers increase R\&D and their firms become less likely to beat analysts' earnings forecasts after the introduction of long-term stock options (LEAPS) for their firm. They argue that the decline in the use of sub-optimal R\&D investment to manage earnings is caused by the new-found ability of informed traders to profit from their long-term superior information through the use of LEAPS. Some firms underinvest in R\&D to manage earnings (Cheng, Subramanyam, \& Zhang, 2007). CEOs spend less on R\&D near the end of their careers presumably so they can reap the benefits of higher short-term earnings in lieu of the long-term benefits of $R \& D$ that they will not be around to enjoy (Dechow \& Sloan, 1991). In contrast, there is research indicating CEOs do not underinvest in R\&D. Gibbons and Murphy (1992) find that R\&D spending tends to be the largest during a CEO's final years in office. Cazier (2011) argues that CEOs that are nearing retirement do not reduce $R \& D$ investment.

Others have demonstrated that institutional investors can have an effect on R\&D investment. Huang and Shiu (2009) find that foreign institutional investor ownership in Taiwanese firms leads to higher R\&D investment and better firm performance. Institutional investors have an influence on $R \& D$ investment in technology and healthcare firms (Le, Walters, \& Kroll, 2006). Institutional investors have been shown to affect R\&D investment through activist actions (David, Hitt, \& Gimeno, 2001).

\section{Hypothesis}

The influence institutional investors can wield is reflected in the view of CFOs that institutional investors important investors that influence stock price and affect cost of capital (Graham et al., 2005). This influence gains empirical evidence from the finding of Gillan and Starks (2007) that institutional investors can influence management through the threat of divesting their shares. The first part of my hypothesis is that institutional investors will encourage management to raise $R \& D$ investment.

Previous research has provided evidence that institutional investors' informational advantage over other investors gives them the ability to be more effective monitors. The superior monitoring ability of institutional investors may vary with the level of firm information asymmetry between insiders and outside shareholders. Zeckhauser and Pound (1990) provide evidence that monitoring by another group of informed investors, shareholders that own more than $15 \%$ of a firm, is only effective in firms with low information asymmetry. This 
indicates that it is possible that institutional shareholders will not be able to effectively monitor R\&D investment in firms with high information asymmetry. On the other hand, institutional investors may be able to more effectively exploit their informational advantage in firms with high information asymmetry leading to more effective monitoring of R\&D in such firms. This conjecture is the basis for my hypothesis.

H1: Institutional investors will encourage higher R\&D investment, especially as information asymmetry increases.

To support my hypothesis, I must demonstrate a causal relationship in which institutional investors effect a change in R\&D investment and not the other way around. Therefore, I must employ statistical methods that establish causality.

\section{Data, Methods and Summary Statistics}

\subsection{Data}

I gather institutional and insider ownership data on U.S. listed companies from CDA/Spectrum Compact Disclosure for each year from 1990 to 2005. I exclude utilities and financial firms because they are highly regulated. I then merge this ownership data with firm characteristic data from Compustat. Firms with missing data or data from too few firm-years to perform required analysis are excluded from that analysis. The final sample consists of 2,769 firms and 18,434 firm-years.

Primarily, I measure R\&D investment as R\&D investment per share (adjusting for stock splits) (Bushee, 1998). I measure $R \& D$ investment as $R \& D$ to assets for some robustness analysis. $R \& D$ to sales has often been used in past research as a measure of $R \& D$ investment. This measure is not appropriate for my analysis because my sample has many small firms with negligible sales. Therefore, using R\&D to sales ironically greatly increases the importance of firms with low sales to regression analysis.

$R \& D$ investment per share is very useful in determining if a firm increased or decreased its R\&D investment, but it fails to provide a useful scale for linear regression analysis. Therefore, I use logit regressions with a binary dependent variable indicating either R\&D increases or decreases. Following (Coles, Daniel, \& Naveen, 2006), I assume missing values of $R \& D$ expenditures are zero.

I use control variables in my regressions to isolate the relationship between institutional ownership and R\&D investment policy. I begin with the same controls used by Wahal and McConnell (2000) in their analysis of institutional investors effect on R\&D with one exception; I substitute $q$ for the book-to-market ratio. Following Dlugosz, Fahlenbrach, Gompers, and Metrick (2006), $q$ is calculated as the market value of assets divided by the book value of assets where market value is calculated as the sum of the book value of assets and the market value of common stock less the book value of common stock and deferred taxes.

I use total debt to total assets as a control because debt competes with R\&D for firm cash flow. Earnings before interest and taxes (EBIT) scaled by total assets is used because earnings are often used to fund R\&D. Insider owners have been shown to influence corporate policies (Morck, Shleifer, \& Vishny, 1988). Therefore, I use insider percentage ownership and insider percentage ownership squared as controls. Firm size is controlled for using $\log$ of sales.

I add control variables to those used by Wahal and McConnell (2000). Capital expenditures compete with R\&D for funds so capital expenditures scaled by assets is used as a control (Bushee, 1998). A control for firm life-cycle, retained earnings to the book value of total equity, which is used by DeAngelo, DeAngelo, and Stulz (2006) is used because R\&D investment tends to change as a firm matures. Log of equity market capitalization is used to control for firm size because smaller firms are more likely to have less cash available for R\&D investment (Jalilvand \& Harris, 1984). Free cash flow scaled by total assets is used because limited cash flow can lead to reduced R\&D (Bushee, 1998). Free cash flow is defined as net income plus depreciation and amortization minus capital expenditures.

Edmans (2009) and Bhide (1993) have theorized that investors with large holdings effect on investment policy is reliant on stock liquidity. Therefore, I use firm stock turnover as a control for liquidity. Firm stock turnover is defined as the number of common shares traded in a year divided by common shares outstanding. Detailed definitions of all variables are shown in Table 1.

\subsection{Methods}

It is important to my analysis to determine is if institutional investors influence $R \& D$ investment. If $R \& D$ investment levels influence institutional investors, this can distort my results. Therefore, I use a regression methodology which establishes causality and controls for endogeneity. Initially, I attempted two-stage least 
squares' regressions with instrumental variables. Unfortunately, I was unable to find instrumental variables which met statistical and conceptual requirements.

Table 1. Variable definitions-R\&D

\begin{tabular}{|c|c|c|}
\hline Variable & Description & Definition \\
\hline \multicolumn{3}{|c|}{ Panel A: Summary Statistics and Correlation Table Variables } \\
\hline$N$ & Number of Firms & The number of firms. \\
\hline Inst & Institutional Ownership & The fraction of shares owned by institutional investors. \\
\hline$R \& D$ & R\&D Expenses & Research and development expenses divided by previous year's sales \\
\hline$q$ & Investment Opportunities & Market value of assets to the book value of assets \\
\hline MktCap & Market Capitalization & The dollar market value of common stock in millions. \\
\hline LifeCycle & Firm Life-cycle & The ratio of retained earnings to total equity. \\
\hline Liquidity & Stock Turnover & Number of common shares traded in a year divided by common shares outstanding \\
\hline$F C F$ & Free Cash Flow & $\begin{array}{l}\text { Net income plus depreciation and amortization minus capital expenditures scaled by } \\
\text { total assets. }\end{array}$ \\
\hline \multicolumn{3}{|c|}{ Panel B: Regression Dependent Variables (Measured as changes in values from year $t-1$ to $t$.) } \\
\hline$R \& D \_I n c r$ & R\&D Increase & $\begin{array}{l}\text { Binary variable equal to one if there is an increase in } R \& D \text { expenses per split-adjusted } \\
\text { common share and zero otherwise. }\end{array}$ \\
\hline$R \& D \_D e c r$ & R\&D Decrease & $\begin{array}{l}\text { Binary variable equal to one if there is a decrease in } R \& D \text { expenses per split-adjusted } \\
\text { common share and zero otherwise. }\end{array}$ \\
\hline$R \& D \_$Assets & R\&D to Assets & R\&D expenses divided by previous year's total assets \\
\hline \multicolumn{3}{|c|}{ Panel C: Regression Independent Variables (Measured as changes in values from year $t-2$ to $t-1$.) } \\
\hline Inst & Institutional Ownership & The fraction of shares owned by institutional investors. \\
\hline$q$ & Investment Opportunities & Market value of assets to the book value of assets \\
\hline Debt & Debt Ratio & Debt to assets. \\
\hline$R O A$ & Return on Assets & Earnings before interest and taxes divided by total assets. \\
\hline Insider & Insider Ownership & The fraction of shares owned by insiders. \\
\hline Insider 2 & Insider Ownership Squared & The squared value of Insider. \\
\hline MktCap & Market Capitalization & The dollar market value of common stock in millions. \\
\hline CapEx & Capital Expenditures & Capital expenditures to total assets \\
\hline$F C F$ & Free Cash Flow & $\begin{array}{l}\text { Net income plus depreciation and amortization minus capital expenditures scaled by } \\
\text { total assets. }\end{array}$ \\
\hline Liquidity & Stock Turnover & Number of common shares traded in a year divided by common shares outstanding \\
\hline LifeCycle & Firm Life-cycle & The ratio of retained earnings to total equity. \\
\hline Revenue & Revenue & The logarithm of firm revenue. \\
\hline
\end{tabular}

I establish causality by using fixed effects regressions on changes in dependent variables from year $t-1$ to $t$ on changes in independent variables from $t-2$ to $t-1$. Firm fixed effect regressions control for all stable characteristics of a firm including industry and unmeasured characteristics. I employ dummy variables for each year to account for time-varying omitted characteristics. Firm fixed effects with yearly dummy variables limit endogeneity problems. An intercept for each firm for each year is created by the use of yearly dummy variables and fixed effects. These intercepts are an average value of the unobserved fixed effects for each firm-year and are not relevant to my analysis. Therefore, their values are not reported.

I add robustness to my results and address potential endogeneity more comprehensively by using a difference generalized method of moments (GMM) methodology based on the Holtz-Eakin, Newey, and Rosen (1988) 
methodology with refinements and validity tests developed by Arellano and Bond (1991). I use the Stata command xtabond2 developed by (Roodman, 2009) to implement the methodology.

The difference GMM methodology is especially useful in panel samples like mine with a limited number of time periods and many firms. My sample consists of a maximum of 16 years of data for over 10,000 firms. Difference GMM uses lagged values of the dependent and independent variables of interest as instruments and removes fixed effects. It avoids endogeneity problems associated with autocorrelation in the dependent variable and with the inclusion of lagged independent variables. Almeida, Campello, and Galvao (2010) find that difference GMM is effective in regressions using sample data that contains firm-fixed effects and heteroskedasticity.

Difference GMM uses lagged endogenous regressors as instruments. This shrinks the sample size because at least one year of data has to be dropped for each firm. In my analysis, I only have to drop one year of data for each firm.

The dependent variables in my regressions depend on past realizations because current R\&D investment policy is largely dependent on past R\&D investment policy. In my difference GMM robustness checks, the independent variables of interest are assumed to be endogenous. In fact, the main purpose of difference GMM robustness checks is to control for the expected endogenous relationship between R\&D investment policy and institutional ownership.

My implementation of difference GMM results in the following model.

$$
\Delta \text { Policy }_{i t}=\Delta \text { Policy }_{i t-1}+\Delta \text { Inst }_{i t-1}+\beta \bullet \Delta \text { Control }_{i t-1}+\Delta \varepsilon_{i t}
$$

In this model, Policy $_{\mathrm{it}}$ represents the change in the firm R\&D investment policy. Policy $y_{\mathrm{it}-1}$ represents the change in firm repurchase policy in the previous year. The independent variable Inst $t_{\mathrm{it}-1}$ represents the change in institutional ownership percentage in the previous year. Control $_{\mathrm{i} t-l}$ represents a vector of time-varying firm level control variables. Year dummies are included as control variables to remove time-related shocks that affect all firms. The $\varepsilon_{i t}$ term represents a time-varying observation-specific error term. The difference GMM methodology uses first-differences thus removing the firm-fixed effects because they are time invariant.

I was able to use the first lag of independent policy and institutional variables in all my regressions as an instrument. I use two tests of model validity which are recommended by Roodman (2009): the Hansen-Sargan $J$-test and the Arellano-Bond test for second-order autocorrelation in differenced residuals. For both tests, a higher $p$-value indicates a valid model while $p$-values of less than 0.10 indicate an invalid model. AR(1) autocorrelation in differenced residuals is expected. The Arellano-Bond test for second-order autocorrelation is important because AR(2) autocorrelation indicates an invalid model. Therefore, I do not use any models in which the null hypothesis of no $\mathrm{AR}(2)$ autocorrelation is rejected at the $10 \%$ level.

\subsection{Summary Statistics}

Table 2 displays sample summary statistics. Panel A includes all firms and panel B includes only firm-years in which the firm made R\&D investments. Statistics are shown for two time periods, 1990-1997 and 1998-2005, and for the total sample. Means are shown and medians are shown in parentheses below.

There are some notable patterns in the statistics. Institutional investors' percentage ownership increases from the early period to the late period. The institutional ownership levels for all firms and for firms that invest in R\&D is rather similar. There is an increase in R\&D expenses to sales from the first period to the next. Skewness in all groups is indicated in the $R \& D$ to sales ratio because the average is much higher than the median. This skewness is the result of a few firms with very large R\&D to sales ratios.

Firm size and $q$ increase also increase in the second time period. Firm life-cycle is proxied by retained earnings to total equity. The ratio is higher for more mature firms. Firms are more mature in the earlier years. This is probably a result of firms conducting initial public offerings as the internet bubble expanded. Firms with R\&D expenses are less mature and have higher liquidity than firms overall.

Table 3 displays selected firm variables correlations. An asterisk denotes correlations that are significant at the 5\% level. R\&D to sales $(R \& D)$ and Tobin's $q(q)$ are inversely related with institutional ownership (Inst). Institutional ownership is positively related to free cash flow to assets $(F C F)$ and the market value of common stock (MktCap). My firm-life cycle proxy, retained equity to total equity (LifeCycle), is not significantly correlated with any of the other variables. 
Table 2. Summary statistics

\begin{tabular}{|c|c|c|c|c|c|c|c|c|}
\hline \multicolumn{9}{|c|}{ Panel A: All Firms } \\
\hline Years & $N$ & Inst & $R \& D$ & $q$ & MktCap & LifeCycle & Liquidity & $F C F$ \\
\hline \multirow[t]{2}{*}{$1990-1997$} & 37492 & $28.9 \%$ & 1.155 & 2.81 & 2106 & -0.69 & 4.46 & -0.16 \\
\hline & & $(23.6 \%)$ & $(0.000)$ & $(1.85)$ & $(163)$ & $(0.29)$ & $(0.64)$ & $(0.01)$ \\
\hline \multirow[t]{2}{*}{$1998-2005$} & 42398 & $33.3 \%$ & 1.656 & 4.68 & 4891 & -0.53 & 4.80 & -0.39 \\
\hline & & $(25.8 \%)$ & $(0.003)$ & $(1.86)$ & $(350)$ & $(0.18)$ & $(0.86)$ & $(0.01)$ \\
\hline \multirow[t]{2}{*}{ Total } & 79890 & $31.3 \%$ & 1.433 & 3.82 & 3603 & -0.61 & 4.64 & -0.28 \\
\hline & & $(24.6 \%)$ & $(0.000)$ & $(1.85)$ & (239) & $(0.24)$ & $(0.74)$ & $(0.01)$ \\
\hline \multicolumn{9}{|c|}{ Panel B: Firms with R\&D Expenses } \\
\hline \multirow[t]{2}{*}{$1990-1997$} & 17240 & $29.8 \%$ & 2.479 & 3.04 & 3007 & -1.75 & 6.88 & -0.11 \\
\hline & & $(24.1 \%)$ & $(0.059)$ & $(2.12)$ & (157) & $(0.26)$ & $(0.75)$ & $(0.02)$ \\
\hline \multirow[t]{2}{*}{$1998-2005$} & 21751 & $33.3 \%$ & 3.197 & 3.97 & 6360 & -0.48 & 6.30 & -0.33 \\
\hline & & $(25.8 \%)$ & $(0.096)$ & $(2.23)$ & (317) & $(0.01)$ & (1.01) & $(-0.00)$ \\
\hline \multirow[t]{2}{*}{ Total } & 38991 & $31.8 \%$ & 2.896 & 3.56 & 4894 & -1.04 & 6.55 & -0.24 \\
\hline & & $(24.9 \%)$ & $(0.078)$ & $(2.18)$ & (226) & $(0.14)$ & $(0.88)$ & $(0.01)$ \\
\hline
\end{tabular}

Means are shown on the first row and medians are shown in parentheses on the second row.

Table 3. Correlations

\begin{tabular}{ccccccc}
\hline & $R \& D$ & Inst & $q$ & MktCap & LifeCycle & Liquidity \\
\hline Inst & $-0.0133^{*}$ & & & & & \\
$q$ & 0.0028 & $-0.0135^{*}$ & & & & \\
MktCap & -0.0049 & $0.0865^{*}$ & -0.0019 & & & \\
LifeCycle & -0.0010 & 0.0013 & 0.0013 & 0.0009 & & \\
Liquidity & -0.0002 & -0.0009 & -0.0003 & -0.0008 & 0.0002 & 0.0000 \\
FCF & -0.0032 & $0.0232^{*}$ & $-0.4194^{*}$ & 0.0023 & -0.0008 & \\
\hline
\end{tabular}

* indicates two-tailed significance at $5 \%$.

\section{The Effect of Institutional Owners and Information Asymmetry on R\&D Investment}

Wahal and McConnell (2000) note that despite the advantages of R\&D investment in the long-term; R\&D reduces current income because it is expensed immediately. This provides an incentive for management to engage in managerial myopia by underinvesting in R\&D. I mimic their method for showing a negative relationship between current $R \& D$ investment and current earnings using my sample.

I use firm fixed effect regressions using current year net income before extraordinary items divided by total assets from the previous year as the dependent variable. Current R\&D expenditures divided by the previous year's sales is the only independent variable. The results, which are not shown in a table, provide evidence for a negative relationship between the two variables.

I run the regression for the entire sample, for 1990-1997, and for 1998-2005. The coefficient is significantly negative in each case with $t$-statistics of $8.58,3.80$ and 5.67 respectively. I run the regression on a yearly basis and the coefficient is negative for each year with a minimum $t$-statistic of 2.10 . The value for $R^{2}$ is over 0.05 for all but two of the years. My findings are similar to that of Wahal and McConnell (2000) in that R\&D investment reduces current earnings.

I use the following firm and year fixed effects logit model to examine the effect that institutional investor ownership levels have on R\&D investment. 


$$
R D C h g_{i t}=\text { Year }_{t}+\text { Firm }_{i}+\text { Inst }_{i t-1}+\beta \bullet \text { Control }_{i t-1}+\varepsilon_{i t}
$$

The dependent variable $R D C h g_{i t}$ is a binary variable set to one if there is an increase in $R \& D$ investment per share. In a robustness check it is set to one if there is a decrease in $R \& D$ investment per share. The independent variable Inst $t_{i-1}$ represents the effect that changes in institutional ownership percentage have on R\&D investment increases (or decreases in the robustness check) in the following year.

Table 4. Institutional ownership and R\&D

\begin{tabular}{|c|c|c|c|c|c|c|}
\hline & (1) & (2) & (3) & (4) & (5) & (6) \\
\hline & All Firms & All Firms & $\begin{array}{l}\text { No R\&D Incr. } \\
\text { in year } t-2\end{array}$ & $\begin{array}{c}\text { R\&D Incr. in } \\
\text { year } t-2\end{array}$ & 1990-1997 & 1998-2005 \\
\hline & $R \& D \_I n c r$ & $R \& D \_I n c r$ & $R \& D \_I n c r$ & $R \& D \_I n c r$ & $R \& D \_I n c r$ & $R \& D \_I n c r$ \\
\hline \multirow[t]{2}{*}{ Inst } & & $0.8576^{* * *}$ & $0.8496^{* * *}$ & $0.6722 * * *$ & $0.8601^{* * *}$ & $0.8353 * * *$ \\
\hline & & (5.54) & (3.13) & (2.95) & (2.73) & $(4.30)$ \\
\hline \multirow[t]{2}{*}{$q$} & $-0.0406 * * *$ & $-0.0374 * * *$ & $-0.0366^{* * *}$ & $-0.0470 * * *$ & $-0.0797 * * *$ & $-0.0290 * * *$ \\
\hline & (4.97) & $(4.64)$ & (2.94) & $(3.23)$ & (3.17) & $(3.46)$ \\
\hline \multirow[t]{2}{*}{ Debt } & -0.0920 & -0.0807 & 0.1262 & $-0.5816^{* *}$ & $-0.7951 * *$ & -0.0231 \\
\hline & (1.18) & (1.04) & (1.10) & (2.39) & $(2.27)$ & $(0.33)$ \\
\hline \multirow[t]{2}{*}{$R O A$} & $0.1942 *$ & $0.1969^{*}$ & -0.0509 & 0.1756 & $0.8265^{* *}$ & 0.1590 \\
\hline & (1.84) & (1.85) & $(0.40)$ & $(0.75)$ & $(2.30)$ & (1.36) \\
\hline \multirow[t]{2}{*}{ Insider } & -0.1552 & -0.1622 & -0.6080 & 0.8499 & -0.8434 & 0.5605 \\
\hline & $(0.46)$ & $(0.48)$ & (1.12) & (1.57) & (1.36) & (1.28) \\
\hline \multirow[t]{2}{*}{ Insider2 } & 0.3269 & 0.3213 & 1.0153 & -0.7765 & $1.2460^{*}$ & -0.7551 \\
\hline & $(0.74)$ & $(0.72)$ & (1.39) & (1.10) & (1.66) & (1.24) \\
\hline \multirow[t]{2}{*}{ MktCap } & $0.6717 * * *$ & $0.6324 * * *$ & $0.6192 * * *$ & $0.6859 * * *$ & $0.5291 * * *$ & $0.5797 * * *$ \\
\hline & (15.48) & (14.48) & (9.16) & (9.06) & (4.93) & (11.33) \\
\hline \multirow[t]{2}{*}{ CapEx } & 0.2181 & 0.1729 & 0.1679 & -0.0410 & -0.2828 & $0.5615^{*}$ \\
\hline & $(0.96)$ & $(0.76)$ & $(0.47)$ & $(0.12)$ & $(0.67)$ & (1.77) \\
\hline \multirow[t]{2}{*}{$F C F$} & $0.1560 * *$ & $0.1637 * * *$ & $0.1714 *$ & $0.3113 * *$ & $0.5970 * *$ & $0.1402 * *$ \\
\hline & $(2.54)$ & (2.59) & (1.89) & $(2.27)$ & $(2.46)$ & (2.04) \\
\hline \multirow[t]{2}{*}{ Liquidity } & -0.0001 & -0.0001 & -0.0001 & 0.0188 & -0.0001 & $0.0215^{*}$ \\
\hline & $(0.24)$ & $(0.23)$ & $(0.18)$ & $(0.98)$ & $(0.13)$ & (1.65) \\
\hline \multirow[t]{2}{*}{ LifeCycle } & 0.0001 & 0.0001 & 0.0001 & $-0.0025^{* *}$ & 0.0001 & 0.0001 \\
\hline & $(0.66)$ & $(0.64)$ & $(0.91)$ & $(2.21)$ & $(0.21)$ & $(0.78)$ \\
\hline \multirow[t]{2}{*}{ Revenue } & $0.0912 * *$ & $0.0849 * *$ & 0.0272 & $0.2382^{* * *}$ & -0.0477 & 0.0572 \\
\hline & $(2.47)$ & $(2.30)$ & $(0.53)$ & (3.37) & $(0.57)$ & $(1.27)$ \\
\hline Observations & 18434 & 18215 & 6627 & 8630 & 4888 & 10919 \\
\hline Number of Firms & 2769 & 2757 & 1607 & 1814 & 1236 & 2126 \\
\hline Pseudo R-sqr. & 0.04 & 0.05 & 0.06 & 0.07 & 0.04 & 0.06 \\
\hline
\end{tabular}

Absolute value of $\mathrm{z}$ statistics in parentheses.

$*$ significant at $10 \%$; ** significant at $5 \%$; *** significant at $1 \%$.

This table reports estimates of firm and year fixed effect logit regressions of increases (from year $t-1$ to $t$ ) in R\&D expenditures $\left(R \& D \_I n c r\right)$. All independent variable values are calculated as changes in that independent variable from year $t-2$ to $t-1$. Regressions (1) and (2) include all firms. Regression (3) includes only firms that had no R\&D increase in year $t-2$ and regression (4) includes only firms that had an R\&D increase in year $t$ - 2. Regression (5) includes the years from 1990 to 1997. Regression (6) includes the years from 1998 to 2005. 
In model 2, Year $r_{t}$ represents year fixed effects and firm fixed effects are represented by Firm $_{i}$. Control ${ }_{i-1}$ is a vector of time-varying firm level control variables which consists of: $q$, debt, ROA, insider ownership, insider ownership squared, log of market capitalization, capital expenditures to assets, free cash flow to assets, stock turnover, retained equity to total equity, and $\log$ of revenue. The error term is denoted by $\varepsilon_{i t}$.

The independent variables are quantified as the change from year $t-2$ to year $t-1$. The dependent variable is quantified as the change in $\mathrm{R} \& \mathrm{D}$ from year $t-1$ to year $t$. Firms that increase their R\&D investment in every year of the sample and firms that don't increase their R\&D investment in any year of the sample are dropped from the regression. This an advantage to the logit model since only firms that change R\&D policy are included in regression samples.

Table 5. Institutional ownership, R\&D, and firm life-cycle

\begin{tabular}{|c|c|c|c|}
\hline & (1) & (2) & (3) \\
\hline & Early LifeCycle & Middle LifeCycle & Late LifeCycle \\
\hline & $R \& D \_I n c r$ & $R \& D \_I n c r$ & $R \& D \_I n c r$ \\
\hline \multirow[t]{2}{*}{ Inst } & $0.6381 * *$ & $0.7078 * * *$ & 0.4883 \\
\hline & (2.09) & $(2.80)$ & $(1.43)$ \\
\hline \multirow[t]{2}{*}{$q$} & $-0.0458 * * *$ & $-0.0334 *$ & -0.0017 \\
\hline & (3.35) & (1.83) & $(0.09)$ \\
\hline \multirow[t]{2}{*}{ Debt } & -0.3202 & $-1.0502 * * *$ & 0.0176 \\
\hline & $(1.08)$ & (2.89) & $(0.26)$ \\
\hline \multirow[t]{2}{*}{$R O A$} & $0.5454 * * *$ & 0.6316 & -0.1661 \\
\hline & $(3.55)$ & $(1.37)$ & $(0.97)$ \\
\hline \multirow[t]{2}{*}{ Insider } & 0.3653 & -0.0498 & -0.6912 \\
\hline & $(0.62)$ & $(0.08)$ & $(0.99)$ \\
\hline \multirow[t]{2}{*}{ Insider 2} & -0.1883 & 0.2393 & 1.0595 \\
\hline & $(0.23)$ & $(0.30)$ & (1.18) \\
\hline \multirow[t]{2}{*}{ MktCap } & $0.5805 * * *$ & $0.6403 * * *$ & $0.5050 * * *$ \\
\hline & $(8.46)$ & $(6.70)$ & $(4.64)$ \\
\hline \multirow[t]{2}{*}{ CapEx } & 0.6182 & 0.1985 & -0.6114 \\
\hline & $(1.58)$ & $(0.50)$ & $(0.91)$ \\
\hline \multirow[t]{2}{*}{$F C F$} & 0.0582 & $0.6432 * *$ & $0.2967^{*}$ \\
\hline & $(0.73)$ & (1.97) & (1.91) \\
\hline \multirow[t]{2}{*}{ Liquidity } & $0.0847 * * *$ & 0.0017 & $-0.0929 * *$ \\
\hline & $(3.84)$ & $(0.09)$ & $(2.03)$ \\
\hline \multirow[t]{2}{*}{ LifeCycle } & 0.0002 & -0.0460 & -0.0002 \\
\hline & $(1.12)$ & $(1.13)$ & $(0.52)$ \\
\hline \multirow[t]{2}{*}{ Revenue } & -0.0130 & 0.1008 & $0.3387 * *$ \\
\hline & $(0.30)$ & $(0.85)$ & $(2.41)$ \\
\hline Observations & 4637 & 5793 & 5693 \\
\hline Number of Firms & 1028 & 1154 & 855 \\
\hline Pseudo R-squared & 0.09 & 0.06 & 0.03 \\
\hline
\end{tabular}

Absolute value of $\mathrm{z}$ statistics in parentheses.

$*$ significant at $10 \%$;* significant at $5 \%$; *** significant at $1 \%$.

This table reports estimates of firm and year fixed effect logit regressions of increases (from year $t-1$ to $t$ ) in R\&D expenditures $\left(R \& D \_I n c r\right)$. All independent variable values are calculated as changes in that independent variable from year $t-2$ to $t-1$. Sample firms used in regressions (1), (2), and (3) include only Early, Middle, and Late LifeCycle firms, respectively. The Early, Middle, and Late LifeCycle groups include the lowest three, middle four, and highest three LifeCycle deciles from year $t-1$, respectively. Deciles are formed on a yearly basis. 
The effects that institutional ownership changes have on per share increases in R\&D investment in the subsequent year are displayed in Table 4. The second regression shows that increased institutional ownership increases the probability that a firm will increase $R \& D$ investment in the ensuing year. This could be because institutional investors tend to invest more in firms that regularly increase their R\&D investment. Therefore, the third regression is run only on firms that did not increase $\mathrm{R} \& \mathrm{D}$ investment in year $t-2$. Once again, an increase in institutional investor ownership increases the probability of an R\&D investment increase in the ensuing year. The last regression is run on firms that increased R\&D investment in year $t-2$. Evidently, institutional investors encourage R\&D investment increases in firms that had previously increased their R\&D as well. The fifth and sixth regressions demonstrate that higher institutional ownership results in increased R\&D for both the 1990 1997 and $1998-2005$ time periods.

Table 6. R\&D and firm life-cycle (GMM)

\begin{tabular}{|c|c|c|c|}
\hline & (1) & (2) & (3) \\
\hline & All Firms & Early LifeCycle & Late LifeCycle \\
\hline & $R \& D \_A s s e t s$ & $R \& D \_$Assets & $R \& D \_$Assets \\
\hline \multirow[t]{2}{*}{ Inst } & $0.0744 * *$ & $0.0950 *$ & 0.0537 \\
\hline & $(2.02)$ & (1.73) & $(0.95)$ \\
\hline \multirow[t]{2}{*}{$R \& D \_$Assets } & $0.2364 * *$ & $0.2167 * *$ & -0.0971 \\
\hline & $(2.43)$ & $(2.45)$ & $(0.55)$ \\
\hline \multirow[t]{2}{*}{$q$} & $0.0392 * * *$ & $0.0357 * * *$ & $0.0415^{*}$ \\
\hline & $(2.73)$ & (3.77) & (1.95) \\
\hline \multirow[t]{2}{*}{ Debt } & -0.0442 & 0.1095 & -0.0130 \\
\hline & $(0.29)$ & $(0.63)$ & $(0.28)$ \\
\hline \multirow[t]{2}{*}{$R O A$} & 0.1129 & -0.0665 & 0.0741 \\
\hline & $(1.21)$ & $(0.62)$ & $(1.15)$ \\
\hline \multirow[t]{2}{*}{ Insider } & $0.9170^{*}$ & $0.6558^{*}$ & -0.0378 \\
\hline & $(1.72)$ & (1.79) & $(0.07)$ \\
\hline \multirow[t]{2}{*}{ Insider 2} & $-1.6853^{* *}$ & $-1.2905^{* *}$ & -0.0613 \\
\hline & $(2.15)$ & (2.18) & $(0.08)$ \\
\hline \multirow[t]{2}{*}{ MktCap } & $-0.1634 * *$ & $-0.1351 * * *$ & -0.1605 \\
\hline & (2.49) & (2.99) & (1.43) \\
\hline \multirow[t]{2}{*}{ CapEx } & -0.0658 & -0.1652 & 0.5296 \\
\hline & $(0.30)$ & $(0.45)$ & $(1.60)$ \\
\hline \multirow[t]{2}{*}{$F C F$} & -0.0575 & 0.0729 & -0.0562 \\
\hline & $(0.61)$ & $(1.02)$ & $(0.77)$ \\
\hline \multirow[t]{2}{*}{ Liquidity } & 0.0000 & 0.0000 & 0.0000 \\
\hline & $(0.13)$ & $(0.01)$ & $(0.68)$ \\
\hline \multirow[t]{2}{*}{ LifeCycle } & 0.0000 & 0.0000 & -0.0004 \\
\hline & $(0.22)$ & $(0.21)$ & $(0.74)$ \\
\hline \multirow[t]{2}{*}{ Revenue } & 0.0074 & $0.1379 * * *$ & -0.0850 \\
\hline & $(0.21)$ & (3.04) & $(1.45)$ \\
\hline Observations & 14341 & 6759 & 7859 \\
\hline Firms & 3127 & 2029 & 1768 \\
\hline Chi2 ( $p$-value) & 0.000 & 0.000 & 0.049 \\
\hline
\end{tabular}




\begin{tabular}{lccl}
\hline$J p$-value & 0.343 & 0.676 & 0.569 \\
$\mathrm{AR}(2) p$-value & 0.610 & 0.189 & 0.213 \\
Inst lag limits & None & None & None \\
$R \& D$ lag limit & 3 & 1 & None \\
\hline
\end{tabular}

Robust $\mathrm{z}$ stats in parentheses: * significant at $10 \%$; ** significant at $5 \%$; *** significant at $1 \%$.

This table reports estimates generated by difference GMM of changes (from year $t-1$ to $t$ ) in R\&D expenditures divided by assets ( $R \& D \_$Assets). All independent variable values are changes from year $t-2$ to $t$ - 1 . Regressions (2) and (3) include only Early and Late LifeCycle firms (the lowest and highest five deciles from year $\mathrm{t}-1$ ), respectively. Deciles are formed on a yearly basis. $J$ is the Hansen-Sargan test of overidentifying restrictions. AR(2) is the Arellano-Bond test of second-order autocorrelation in the errors. Independent variables Inst and $R \& D \_$Assets are instrumented using GMM-type instrument lags. The maximum available lags which produce a valid model are used.

An increase in institutional investor ownership percentage generally leads to increased R\&D investment, no matter if the firm increased their $R \& D$ investment in the previous year or not.

A logical extrapolation from this finding is that institutional owners will discourage $R \& D$ decreases. I verified this by running regressions identical to those in Table 4, but with a decrease in R\&D investment as the binary dependent variable. The results (not displayed) are virtually a mirror image of the Table 4 results indicating that institutional owners discourage cuts in R\&D.

My hypothesis states that institutional investors will encourage R\&D investment more in firms that have high information asymmetry because their superior monitoring ability will allow them to discern the value of R\&D investments more readily in such firms. I test this hypothesis using retained earnings to total equity (LifeCycle) as a proxy for information asymmetry. DeAngelo et al. (2006) use this measure as a proxy for firm life-cycle. They assert that this is a valid proxy for firm information asymmetry. This assertion appears logical because the more mature a firm is the more information an investor will have about the firm to judge its prospects, all else being equal.

I sort the sample of firms each year into information asymmetry deciles. I assign each firm-year to one of three groups. Firms in the bottom three deciles (Early LifeCycle) have high information asymmetry, those in the next four deciles (Middle LifeCycle) have moderate information asymmetry, and those in the highest three deciles (Late LifeCycle) have low information asymmetry.

The median R\&D to sales ratio for firm-years in which a firm made an R\&D investment in the early, middle, and late LifeCycle groups are $19.26 \%, 6.95 \%$ and $3.40 \%$ respectively. The percentage of firm-years in which the firm made an R\&D investment in the early, middle, and late LifeCycle groups are 60\%, 44\% and $47 \%$ respectively. Thus, firms earlier in their LifeCycle (with higher information asymmetry) are prone to invest more and more often in R\&D.

I run regressions using the firm and year fixed effects model 2 that shows the effect that changes in institutional ownership have on $R \& D$ investment increases in the subsequent year. Regressions are run on the early, middle, and late LifeCycle groups separately based on which group a firm is in during year $t-1$. The results are shown in Table 5 .

The first two regressions show that institutional investors encourage $R \& D$ increases in firms with high and moderate information asymmetry. The third regression shows that institutional investors do not encourage R\&D investment increases at a significant level in firms with low information asymmetry. The pattern indicates that institutional investors encourage $R \& D$ investment more in firms with higher information asymmetry.

Table 6 displays my results using the Arellano and Bond (1991) difference linear GMM dynamic panel data methodology. This methodology controls for endogeneity issues. Difference GMM is a linear method. Therefore, I use changes in $\mathrm{R} \& \mathrm{D}$ to assets as my dependent variable when using this method. The results indicate that increased institutional investor ownership levels gives rise to an increase in $R \& D$ investment. Regression 2 indicates that increased institutional investor ownership levels leads to increased $R \& D$ in firms with high information asymmetry. Institutional investors have no significant effect on R\&D in firms with high information asymmetry (regression 3).

In another robustness check which is displayed in Table 7, I use R\&D intensity (R\&D to total assets) instead of firm life-cycle (retained earnings to the book value of total equity) as a proxy for firm information asymmetry 
and get results which indicate that institutional investors encourage R\&D in all firms, but this relationship appears to get stronger as R\&D intensity (and information asymmetry) increases.

My results are consistent with the assertion that the superior monitoring ability of institutional investors allows them to discern the value of $R \& D$ investments more readily than other investors, even in firms with high information asymmetry.

Table 7. R\&D and R\&D Intensity

\begin{tabular}{|c|c|c|c|}
\hline & (1) & (2) & (3) \\
\hline & Low $R \& D \_A s s e t s$ & Medium $R \& D \_$Assets & High $R \& D \_$Assets \\
\hline & $R \& D \_I n c r$ & $R \& D \_I n c r$ & $R \& D \_I n c r$ \\
\hline \multirow[t]{2}{*}{ Inst } & $0.6061 *$ & $0.6958 * *$ & $1.3596^{* * *}$ \\
\hline & (1.90) & (2.48) & $(4.41)$ \\
\hline \multirow[t]{2}{*}{$q$} & $-0.0992^{*}$ & $-0.1526^{* * *}$ & $-0.0467 * * *$ \\
\hline & $(1.71)$ & $(5.61)$ & $(4.22)$ \\
\hline \multirow[t]{2}{*}{ Debt } & -0.1701 & -0.1101 & 0.0520 \\
\hline & $(0.52)$ & $(0.37)$ & $(0.45)$ \\
\hline \multirow[t]{2}{*}{$R O A$} & 0.2177 & $0.8210^{* *}$ & -0.0103 \\
\hline & $(0.50)$ & $(2.47)$ & $(0.06)$ \\
\hline \multirow[t]{2}{*}{ Insider } & -0.7198 & 0.1148 & 0.8346 \\
\hline & (1.08) & $(0.18)$ & $(1.15)$ \\
\hline \multirow[t]{2}{*}{ Insider2 } & 0.9051 & -0.0948 & -0.9809 \\
\hline & (1.05) & $(0.11)$ & $(1.00)$ \\
\hline \multirow[t]{2}{*}{ MktCap } & $0.7306^{* * *}$ & $0.9929 * * *$ & $0.7954 * * *$ \\
\hline & $(5.15)$ & (9.19) & $(9.95)$ \\
\hline \multirow[t]{2}{*}{ CapEx } & 0.8465 & 0.7958 & $0.8958 * *$ \\
\hline & $(1.45)$ & $(1.62)$ & (1.97) \\
\hline \multirow[t]{2}{*}{$F C F$} & 0.0500 & 0.1900 & $0.4066^{* * *}$ \\
\hline & (1.05) & $(1.25)$ & $(2.76)$ \\
\hline \multirow[t]{2}{*}{ Liquidity } & 0.0199 & 0.0156 & -0.0001 \\
\hline & $(0.49)$ & $(0.83)$ & $(0.16)$ \\
\hline \multirow[t]{2}{*}{ LifeCycle } & 0.0036 & 0.0003 & -0.0000 \\
\hline & $(1.50)$ & $(0.84)$ & $(0.09)$ \\
\hline \multirow[t]{2}{*}{ Revenue } & 0.0361 & $0.1874^{*}$ & 0.0331 \\
\hline & $(0.26)$ & (1.69) & $(0.60)$ \\
\hline Observations & 4848 & 6044 & 3856 \\
\hline Number of Firms & 828 & 1145 & 817 \\
\hline Pseudo R-squared & 0.03 & 0.08 & 0.12 \\
\hline
\end{tabular}

Absolute value of $\mathrm{z}$ statistics in parentheses.

* significant at $10 \%$; ** significant at $5 \%$; *** significant at $1 \%$.

This table reports estimates of firm and year fixed effect logit regressions of increases (from year $t-1$ to $t$ ) in R\&D expenditures $\left(R \& D \_I n c r\right)$. All independent variable values are calculated as changes in that independent variable from year $t-2$ to $t-1$. Sample firms used in regressions (1), (2), and (3) include only Low, Medium and High $R \& D \_$Assets firms, respectively. The Low, Medium and High $R \& D \_A s s e t s$ groups include the lowest three, middle four, and highest three Liquidity deciles from year $t-1$, respectively. Deciles are formed on a yearly basis. 


\section{Discussion}

Institutional investors are important owners of U.S. corporations, owning approximately $70 \%$ of U.S. publicly owned shares. The amount of investment that a firm allocates to research and development (R\&D) is an important policy decision for many corporations.

Institutional investors are better informed than other investors. Institutional owners should be able to gauge the long-term benefit of R\&D investment more precisely than non-institutional investors. Therefore, I propose a hypothesis that predicts that the positive relationship between institutional investors and future R\&D investment will strengthen in firms with higher information asymmetry. My results support this prediction. I find that Institutional investors encourage higher R\&D investment primarily in firms with high information asymmetry indicating they have an advantage in discerning the value of R\&D investments in such firms.

This study is limited to U.S. listed stocks and thus is only directly applicable to U.S. firms and the institutional investors that invest in them. Further research is required to see if the findings here can be expanded to include firms from other countries.

Institutional investor increases precede increases in research and development (R\&D) investment overall and specifically in firms with higher information asymmetry. Institutional investors effectively induce management to conduct long-term $R \& D$ investment policies that are advantageous to the firm. This should increase firm value and benefit all owners of the company. Additionally, this should benefit the management of the firm as they are encouraged to invest in R\&D projects that may only benefit the company in the long-term. Determining if firm value actually increases from the influence of institutional investors on $R \& D$ investment policy is a subject for future research.

\section{References}

Aboody, D., \& Lev, B. (2000). Information Asymmetry, R\&D, and Insider Gains. Journal of Finance, 55(6), 2747-2766. http://dx.doi.org/10.1111/0022-1082.00305

Almazan, A., Hartzell, J. C., \& Starks, L. T. (2005). Active institutional shareholders and costs of monitoring: Evidence from executive compensation. Financial Management, 34(4), 5-34. http://dx.doi.org/10.1111/j.1755-053X.2005.tb00116.x

Almeida, H., Campello, M., \& Galvao, A. F. (2010). Measurement errors in investment equations. Review of Financial Studies, 23(9), 3279-3328. http://dx.doi.org/10.1093/rfs/hhq058

Arellano, M., \& Bond, S. (1991). Some tests of specification for panel data: Monte Carlo evidence and an application to employment equations. The Review of Economic Studies, 58(2), 277-297. http://dx.doi.org/10.2307/2297968

Baber, W. R., Fairfield, P. M., \& Haggard, J. A. (1991). The effect of concern about reported income on discretionary spending decisions: The case of research and development. Accounting Review, 66(4), 818-829.

Bange, M. M., \& De Bondt, W. F. (1998). R\&D budgets and corporate earnings targets. Journal of Corporate Finance, 4(2), 153-184. http://dx.doi.org/10.1016/S0929-1199(98)00006-6

Bennett, J. A., Sias, R. W., \& Starks, L. T. (2003). Greener pastures and the impact of dynamic institutional preferences. Review of Financial Studies, 16(4), 1203-1238. http://dx.doi.org/10.1093/rfs/hhg040

Bhide, A. (1993). The hidden costs of stock market liquidity. Journal of Financial Economics, 34(1), 31-51. http://dx.doi.org/10.1016/0304-405X(93)90039-E

Bhojraj, S., Hribar, P., Picconi, M., \& McInnis, J. (2009). Making sense of cents: An examination of firms that marginally miss or beat analyst forecasts. The Journal of Finance, 64(5), 2361-2388. http://dx.doi.org/10.1111/j.1540-6261.2009.01503.x

Bhojraj, S., \& Libby, R. (2005). Capital market pressure, disclosure frequency-induced earnings/cash flow conflict, and managerial myopia. The Accounting Review, 80(1), 1-20. http://dx.doi.org/10.2308/accr.2005.80.1.1

Bogle, J. C. (2010, 19 January). Restoring Faith in Financial Markets. The Wall Street Journal, p. A17.

Bushee, B. J. (1998). The influence of institutional investors on myopic R\&D investment behavior. Accounting Review, 73(3), 305-333.

Cazier, R. A. (2011). Measuring R\&D curtailment among short-horizon CEOs. Journal of Corporate Finance, 
17(3), 584-594. http://dx.doi.org/10.1016/j.jcorpfin.2011.02.005

Chan, L. K., Lakonishok, J., \& Sougiannis, T. (2001). The Stock Market Valuation of Research and Development Expenditures. Journal of Finance, 56(6), 2431-2456. http://dx.doi.org/10.1111/0022-1082.00411

Chemmanur, T. J., He, S., \& Hu, G. (2009). The role of institutional investors in seasoned equity offerings. Journal of Financial Economics, 94(3), 384-411. http://dx.doi.org/10.1016/j.jfineco.2008.12.011

Cheng, M., Subramanyam, K., \& Zhang, Y. (2007). Earnings Guidance and Managerial Myopia. Working paper, Kellogg School of Management, Northwestern University, Evanston.

Coles, J. L., Daniel, N. D., \& Naveen, L. (2006). Managerial incentives and risk-taking. Journal of Financial Economics, 79(2), 431-468. http://dx.doi.org/10.1016/j.jfineco.2004.09.004

David, P., Hitt, M. A., \& Gimeno, J. (2001). The Influence of Activism by Institutional Investors on R\&D. Academy of Management Journal, 44(1), 144-157. http://dx.doi.org/10.2307/3069342

DeAngelo, H., DeAngelo, L., \& Stulz, R. M. (2006). Dividend policy and the earned/contributed capital mix: a test of the life-cycle theory. Journal of Financial Economics, 81(2), 227-254. http://dx.doi.org/10.1016/j.jfineco.2005.07.005

Dechow, P. M., \& Sloan, R. G. (1991). Executive incentives and the horizon problem: An empirical investigation. Journal of Accounting and Economics, 14(1), 51-89. http://dx.doi.org/10.1016/0167-7187(91)90058-S

Dlugosz, J., Fahlenbrach, R., Gompers, P., \& Metrick, A. (2006). Large blocks of stock: Prevalence, size, and $\begin{array}{llll}\text { measurement. Journal of } & \text { Corporate }\end{array}$ http://dx.doi.org/10.1016/j.jcorpfin.2005.04.002

Eberhart, A. C., Maxwell, W. F., \& Siddique, A. R. (2004). An Examination of Long - Term Abnormal Stock Returns and Operating Performance Following R\&D Increases. The Journal of Finance, 59(2), 623-650. http://dx.doi.org/10.1111/j.1540-6261.2004.00644.x

Edmans, A. (2009). Blockholder trading, market efficiency, and managerial myopia. The Journal of Finance, 64(6), 2481-2513. http://dx.doi.org/10.1111/j.1540-6261.2009.01508.x

Field, L. C., \& Lowry, M. (2009). Institutional versus individual investment in IPOs: The importance of firm fundamentals. Journal of Financial and Quantitative Analysis, 44(3), 489-516. http://dx.doi.org/10.1017/S0022109009990032

Froot, K. A., Perold, A. F., \& Stein, J. C. (1992). Shareholder Trading Practices And Corporate Investment $\begin{array}{llll}\text { Horizons. Journal of Applied } & \text { Corporate }\end{array}$ http://dx.doi.org/10.1111/j.1745-6622.1992.tb00489.x

Gibbons, R., \& Murphy, K. J. (1992). Does Executive Compensation Affect Investment? Journal of Applied Corporate Finance, 5(2), 99-109. http://dx.doi.org/10.1111/j.1745-6622.1992.tb00493.x

Gillan, S. L., \& Starks, L. T. (2007). The Evolution of Shareholder Activism in the United States. Journal of Applied Corporate Finance, 19(1), 55-73. http://dx.doi.org/10.1111/j.1745-6622.2007.00125.x

Graham, J. R., Harvey, C. R., \& Rajgopal, S. (2005). The economic implications of corporate financial reporting. Journal of Accounting and Economics, 4O(1), 3-73. http://dx.doi.org/10.1016/j.jacceco.2005.01.002

Harter, C. I., \& Harikumar, T. (2004). Management Compensation And Project Life. Journal of Applied Business Research (JABR), 20(4), 65-71.

Holden, C. W., \& Lundstrum, L. L. (2009). Costly trade, managerial myopia, and long-term investment. Journal of Empirical Finance, 16(1), 126-135. http://dx.doi.org/10.1016/j.jempfin.2008.05.001

Holtz-Eakin, D., Newey, W., \& Rosen, H. S. (1988). Estimating vector autoregressions with panel data. Econometrica: Journal of the Econometric Society, 56(6), 1371-1395.

Huang, R. D., \& Shiu, C. Y. (2009). Local effects of foreign ownership in an emerging financial market: Evidence from qualified foreign institutional investors in Taiwan. Financial Management, 38(3), 567-602. http://dx.doi.org/10.1111/j.1755-053X.2009.01048.x

Jalilvand, A., \& Harris, R. S. (1984). Corporate Behavior in Adjusting to Capital Structure and Dividend Targets: An Econometric Study. The Journal of Finance, 39(1), 127-145. http://dx.doi.org/10.1111/j.1540-6261.1984.tb03864.x

Jensen, M. (1986). Agency cost of free cash flow, corporate finance, and takeovers. Corporate Finance, and 
Takeovers. American Economic Review, 76(2), 323-329.

Kothari, S., Laguerre, T. E., \& Leone, A. J. (2002). Capitalization versus expensing: Evidence on the uncertainty of future earnings from capital expenditures versus R\&D outlays. Review of Accounting Studies, 7(4), 355-382. http://dx.doi.org/10.1023/A:1020764227390

Le, S. A., Walters, B., \& Kroll, M. (2006). The moderating effects of external monitors on the relationship between R\&D spending and firm performance. Journal of Business Research, 59(2), 278-287. http://dx.doi.org/10.1016/j.jbusres.2005.04.003

Maug, E. (1998). Large Shareholders as Monitors: Is There a Trade-Off between Liquidity and Control? Journal of Finance, 53(1), 65-98. http://dx.doi.org/10.1111/0022-1082.35053

Morck, R., Shleifer, A., \& Vishny, R. W. (1988). Management ownership and market valuation: An empirical $\begin{array}{llll}\text { analysis. Journal of } & \text { Financial 20(1), }\end{array}$ http://dx.doi.org/10.1016/0304-405X(88)90048-7

Parrino, R., Sias, R. W., \& Starks, L. T. (2003). Voting with their feet: Institutional ownership changes around forced CEO turnover. Journal of Financial Economics, 68(1), 3-46. http://dx.doi.org/10.1016/S0304-405X(02)00247-7

Porter, M. E. (1992). Capital disadvantage: America's failing capital investment system. Harvard Business Review, 70(5), 65-82.

Roodman, D. (2009). How to do xtabond2: An introduction to difference and system GMM in Stata. Stata Journal, 9(1), 86-136.

Samuel, C. (2000). Does shareholder myopia lead to managerial myopia? A first look. Applied Financial Economics, 10(5), 493-505. http://dx.doi.org/10.1080/096031000416370

Stein, J. C. (1988). Takeover threats and managerial myopia. The Journal of Political Economy, 96(1), 61-80.

Stein, J. C. (1989). Efficient capital markets, inefficient firms: A model of myopic corporate behavior. The Quarterly Journal of Economics, 104(4), 655-669.

Sundaram, A. K., John, T. A., \& John, K. (1996). An empirical analysis of strategic competition and firm values the case of R\&D competition. Journal of Financial Economics, 40(3), 459-486. http://dx.doi.org/10.1016/0304-405X(95)00853-7

Wahal, S., \& McConnell, J. J. (2000). Do institutional investors exacerbate managerial myopia? Journal of Corporate Finance, 6(3), 307-329. http://dx.doi.org/10.1016/S0929-1199(00)00005-5

Zeckhauser, R. J., \& Pound, J. (1990). Are large shareholders effective monitors? An investigation of share ownership and corporate performance. In R. G. Hubbard (Ed.), Asymmetric information, corporate finance, and investment (pp. 149-180). Chicago: University of Chicago Press, 1990.

\section{Copyrights}

Copyright for this article is retained by the author(s), with first publication rights granted to the journal.

This is an open-access article distributed under the terms and conditions of the Creative Commons Attribution license (http://creativecommons.org/licenses/by/3.0/). 